\title{
SMALL BUSINESS, STATUS POLITICS, AND THE SOCIAL BASE OF NEW CHRISTIAN RIGHT ACTIVISM
}

\author{
VAL BURRIS \\ University of Oregon
}

\begin{abstract}
This paper examines the social base of Christian Right activism, using data on approximately 3,000 members and financial supporters of a single state-level Christian Right organization: the Oregon Citizens' Alliance (OCA). The findings of the study are consistent with theories that identify "status anxiety" among marginal or threatened segments of the middle class as a motivation for right-wing activism. The class of small business owners was the most overrepresented group among OCA activists. Members of the salaried middle class were also overrepresented, although to a lesser degree. Contrary to expectations, OCA activism was not disproportionately high among elderly persons or in the most rural areas of the state. The paper also illustrates the prevalence of status concerns in the rhetoric of the OCA's anti-abortion and anti-gay campaigns.
\end{abstract}

The rise of the New Christian Right has been the focus of extensive study in recent years. Despite a great volume of scholarly research, there is, as yet, little solid evidence on the basic question of who supports the Christian Right. This is particularly true with regard to the social characteristics of those who are activists - i.e., leaders, members, and/or financial supporters of Christian Right organizations. While there are numerous surveys of the general public that allow researchers to identify the kinds of persons who express positive attitudes toward Christian Right groups, personalities, or issues, information on those who support the Christian Right in more active ways has been difficult to obtain. This reflects both the distrust with which Christian Right organizations view the social scientific community as well as the proprietary interest they have in restricting access to their membership lists. As a result, only a few surveys of Christian Right activists have been conducted. Most of these involve very limited samples and some are now quite dated.

In this paper I present new evidence on activists in one Christian Right organization: the Oregon Citizens' Alliance (OCA). During the early 1990s, the OCA emerged as one of the most powerful state-level Christian Right organizations in the country, attracting national attention in 1992 and 1994 for its emotionally charged campaigns to restrict gay rights through statewide ballot initiatives. What distinguishes the OCA from other Christian Right groups, such as the Christian Coalition 
or the (now defunct) Moral Majority, is that the OCA is legally incorporated as a political action committee. Under Oregon law, political action committees must comply with strict reporting requirements regarding their receipts and expenditures. These include providing the state election division with the names, addresses, occupations, and employers of all persons who have contributed more than $\$ 50$ in any election cycle. This information, which is publicly accessible, was used as the primary basis for this study. Although limited in scope, these data are more complete (and arguably more reliable) than anything previously available on the active supporters of a Christian Right group. They therefore provide us with an opportunity to explore certain dimensions of the social base of Christian Right activism in more detail and with greater confidence than has heretofore been possible.

The findings of this study are consistent with hypotheses derived from some of the classical theories of right-wing movements - those stressing "status anxiety" among marginal or threatened segments of the middle class as an underlying motivation for right-wing political activism. By and large, these classical theories have fallen out of favor among scholars who study the Christian Right. On the basis of the evidence presented in this paper, I argue that such theories deserve to be treated more seriously in future research.

\section{Theories of Support for the Christian Right}

Theories of support for the Christian Right can be divided into two general categories. The first approach focuses on conditions of social strain or insecurity and views right-wing activism as an attempt by persons in these situations to preserve or enhance their social status. The second approach focuses on deeply held beliefs and values acquired through socialization and sees right-wing activism as simply a way of putting these beliefs and values into practice. ${ }^{1}$

The classical literature on support for right-wing movements gave primacy to explanations framed in terms of status anxiety. Theories of this kind were first proposed by European scholars in the 1920s and 1930 s in an attempt to grasp the historical circumstances responsible for the rise of fascism and the reasons for its appeal to particular social classes (Geiger 1930; Laswell 1933; Fromm 1941; Neumann 1951). The central claim of this literature was that fascism was primarily an expression of "status panic" among the marginal segments of the middle class in a period of economic crisis and cultural change. Fascist ideology was seen as uniquely tailored to status anxieties of the lower middle class 
(especially the class of small farmers and business owners) who resented the expanding power of big business and big government above them, feared being overtaken by an increasingly organized and powerful working class beneath them, and lamented the declining value of thrift, hard work, and patriarchal authority upon which their claims to status had traditionally rested. Brought to the United States by European scholars fleeing the rise of Hitler, these theories were adapted to American rightwing movements by social scientists writing in the postwar era (Mills 1951; Lipset 1960; Bell 1963; Hofstadter 1967; Lipset and Raab 1978).

The status anxiety thesis predicts that support for extreme right-wing movements will be greatest within marginal or threatened segments of the middle class. According to the most common interpretation, the hard core of right-wing activism is expected to be found within the class of small business owners: shopkeepers, small farmers, real estate agents, building contractors, restaurant owners, and the like. This is said to reflect the precariousness and declining prestige of middle-class positions that are based on small property ownership and individual hard work in an era marked by the rise of large-scale bureaucracies that place a higher premium on educational credentials and skill in manipulating information. Other persons with a tenuous hold on middle-class respectability are also expected to be overrepresented within right-wing movements. Some interpretations of the theory place lower white-collar employees (clerical and sales workers) in this category. Other versions of the theory argue that an affinity for right-wing activism is characteristic of upwardly mobile persons who have only recently gained a toe-hold in the middle class and who fear slipping back into the working class.

Evidence for the status anxiety thesis is limited mainly to studies of European fascism and other secular right-wing movements. A number of studies have confirmed the overrepresentation of the lower middle classes - especially the class of small business owners - among activists and supporters of right-wing movements. Analyses of Nazi membership lists showed independent proprietors to be the most overrepresented of all occupational groups (Gerth 1940; Bracher 1970). Other studies showed a strong correlation between electoral support for the Nazi Party and the proportion of independent proprietors in different regions (Loomis and Beegle 1946; Pratt 1948; Childers 1976). In the American context, Wallerstein (1954) and Trow (1957) found small businessmen to be heavily overrepresented among supporters of Joseph McCarthy, and Rohter (1969) found lower middle-class occupations to be overrepresented in a sample of John Birch Society members and right-wing newspaper letter writers. 
The least supported variant of the status anxiety thesis is the argument linking clerical, sales, and other routine white-collar employees with support for right-wing movements. Studies of Nazi leaders and voters failed to demonstrate disproportionate support among lower whitecollar employees (Lerner 1951; Childers 1976; Hamilton 1982). The thesis has also received little support in studies of the American Right and has been challenged theoretically by critics who question the applicability of the "marginal middle class" label to routine white-collar employees and who argue that routine nonmanual workers are not fundamentally different from manual workers in their political behavior (Hamilton 1975; Burris 1986).

One offshoot of the status anxiety thesis maintains that persons with discrepant rankings on any two status dimensions (e.g., high prestige and low income, or high income and low education) are inhibited from establishing a secure sense of their place in the social hierarchy and are therefore predisposed to extremist politics of either the right or the left (Lenski 1954). This "status inconsistency" thesis has been rightly criticized as being so open-ended that it can be made to fit almost any situation (Bruce 1988:5). Unfortunately, because it is easily operationalized with limited survey data, this thesis has been favored by researchers seeking to explain support for right-wing movements (Trow 1957; Lipset 1963; Rush 1967; Grupp 1969; Wolfinger et al. 1969; Hunt and Cushing 1970; Eitzen 1970; Crespi 1971; McEvoy 1971; Wilson and Zurcher 1976; Wood and Hughes 1984; Simpson 1985). These studies have yielded no consistent pattern of empirical findings (Stryker and Macke 1978; Lo 1982).

Studies of the social base of Christian Right activism are limited and few of these provide evidence that is relevant to the status anxiety thesis. The theory was examined and rejected in one of the earliest (and still most widely cited) surveys of Christian Right activists. Wolfinger et al. (1969) analyzed mail questionnaires from 308 persons who attended a 1962 seminar sponsored by the Christian Anti-Communism Crusade in Oakland, California. They found a preponderance of middle-class persons among their sample, but no evidence that Crusaders were disproportionately drawn from new arrivals to the middle class and no evidence of an inconsistency between education and occupational status. They did not report whether or not small businessmen were overrepresented in their sample, nor did they attempt to disaggregate their sample into more detailed occupational categories (other than to note the disproportionate number of clergy). The small sample size of the study, as well as the low response rate ( 38 percent) should lead us to be cautious 
about accepting these findings. The fact that the sample was neither especially religious (only one-half attended church regularly) nor especially conservative (42 percent favored Nixon over Goldwater among candidates for the 1964 Republican presidential nomination) also suggests that those attending this highly publicized event may not have been representative of Christian Right activists.

Among studies of the New Christian Right, the strongest support for the status anxiety thesis comes from Wald, Owen, and Hill's (1989) survey of 673 churchgoers in a Southern community. Using an attitudinal scale of subjectively felt status discontent as their independent variable, they found that it compared favorably with other variables in predicting support for the New Christian Right. They did not report whether particular occupational groups were overrepresented among Christian Right supporters. In their discussion of their findings, however, they argued that subjectively felt status discontent was only loosely associated with objective locations in the occupational hierarchy. The implications of their findings for explaining Christian Right activism are uncertain, since the dependent variable in their study was an index combining conservative attitudes on moral issues, sympathy for Christian Right organizations, and overt activity in support of such groups. Only 72 of their respondents could be classified as activists in the sense that they reported any contribution of time or money to a Christian Right organization.

Other studies have surveyed Moral Majority members in several states. Wilcox (1992) surveyed 149 members of the Ohio Moral Majority and reported that, apart from the disproportionate number of Baptist preachers, the social-status characteristics of Moral Majority members resembled those of political activists in other organizations-i.e., they had higher than average levels of education and occupational status. Georgianna (1989) reported similar findings based on her survey of 162 Indiana Moral Majority members. Neither study attempted to present a more detailed demographic breakdown of Moral Majority activists, nor would this have been possible given the small samples involved. Several studies have also surveyed contributors to and delegates for Pat Robertson in his 1988 presidential campaign (Green and Gurth 1988; Wilcox 1992), but these studies are also based on small samples that provide limited information on the demographic characteristics of Christian Right activists.

Finally, there is one prior study of Oregon Citizens' Alliance activists that, despite its small sample, yielded suggestive findings. Lunch (1995) surveyed 46 activists attending the initial OCA state convention in 1987. He reported that the typical delegate had "some college," but not a 
degree, and relatively high household income (between fifty and sixty thousand dollars per year). This combination of modest education and relatively high income is consistent with some interpretations of status anxiety theory.

The dearth of research on the status characteristics of Christian Right activists is partly attributable to the difficulty of obtaining sufficiently large and representative samples with which to address this issue, but it also reflects a theoretical shift in the literature on right-wing movements. As Wilcox (1992:30) notes:

[E]xplanations that center on individual social status were commonly accepted during the 1960s.... However, the paucity of supporting evidence led later generations of social scientists to largely abandon these explanations. Few of the studies of support for the Christian Right have attempted to assess the role of individual social status concerns on support for the New Christian Right.

I would question Wilcox's assertion that status-based explanations of Christian Right activism have been abandoned for reasons of evidence. The classical literature on right-wing movements presents an array of supportive evidence and the evidence regarding the New Christian Right is more inconclusive than negative. Nevertheless, I agree with Wilcox's characterization of the field as having turned to different theories to explain Christian Right activism.

The currently favored approach to explaining Christian Right activism focuses on the role of belief and value congruity in producing support for Christian Right organizations. Put simply, this thesis maintains that "those who share the goals and values of the [Christian] Right will support its organizations" (Wilcox 1992:35). Evidence for this thesis consists of numerous studies showing that fundamentalist religious beliefs and traditional moral values are strong predictors of support for and/or participation in Christian Right organizations (Tamney and Johnson 1983, 1988; Johnson and Tamney 1984; Harper and Leicht 1984; Guth and Green 1987, Sigelman, Wilcox, and Buell 1987; Johnson, Tamney, and Burton 1989; Wilcox 1992).

Whether this qualifies as an explanation or only a tautology depends upon the origin of the beliefs and values in question. It is possible that the beliefs and values that predict support for the Christian Right developed simultaneously with the affinity for the Christian Right-perhaps in reaction to the social strains hypothesized by status anxiety theory. It is even possible that they are learned responses that result from, rather than cause, involvement in the Christian Right. To avoid the charge 
of tautology, proponents of this view must posit that the beliefs and values in question are independent of and antecedent to Christian Right activism. This claim is usually defended with the argument that conservative beliefs and values are acquired during childhood socialization and remain relatively stable throughout adulthood. As a generalization about the socialization process, this argument is uncontroversial. As an explanation of Christian Right activism, however, the thesis is more problematic. The notion that childhood socialization explains who becomes active in the Christian Right is hard to square with the evangelical self-concept of right-wing Christianity (with its emphasis on the conversion of nonbelievers) and with evidence of the effectiveness of the Christian Right in recruiting supporters from across traditional partisan lines.

Whatever conclusion one reaches on this issue, it is clear that the belief and value congruity thesis represents a significant departure from the explanatory focus of the status anxiety thesis. While the latter theory locates the roots of right-wing activism in the strains and rifts of the stratification system, the former looks to processes of cultural transmission to explain who becomes a right-wing activist. Because of its focus on the cultural determinants of right-wing activism, the belief and value congruity thesis has little to say about the socioeconomic base of rightwing movements. In terms of demographic variables, the main hypotheses suggested by this perspective are that Christian Right activism should be greater among older persons and among those raised in rural areas or the South because of their greater likelihood of exposure to socially conservative beliefs and values during the process of socialization. ${ }^{2}$

It should be emphasized that these two theoretical approaches are not mutually exclusive. It is possible - indeed likely - that recruitment to Christian Right activism depends upon a complex interaction between culturally transmitted values and the objective (and subjectively felt) life circumstances of specific socioeconomic statuses. Evidence in favor of one of these theoretical approaches should not, therefore, be taken as evidence against the other. Nevertheless, the two theories do direct our attention toward different types of explanatory variables, some of which may prove more effective than others in predicting the likelihood of Christian Right activism.

\section{A Brief History of the Oregon Citizens' Alliance}

The OCA was founded in 1987 as a spin-off of the 1986 Senate campaign of Joe Lutz, a fundamentalist preacher who wrested 42 percent of the Republican primary vote from pro-choice incumbent Bob 
Packwood. ${ }^{3}$ Lon Mabon, Lutz's campaign manager for the southern third of the state, became OCA chairman, and several other campaign aides assumed leading roles in the organization. Early OCA organizing efforts included opposition to state-aided pre-school as "anti-family," opposition to parental leave as "anti-business," and opposition to divestment in South African as "harmful" to South African blacks. These early campaigns were relatively unsuccessful in influencing the political debate or in building the OCA as an organization.

The OCA got its first big opening in 1988 when then-Governor Neil Goldschmidt issued an executive order barring state agencies from discriminating on the basis of sexual orientation. The OCA immediately set about the task of collecting the 63,000 signatures required to place an initiative on the November ballot to overturn the governor's order. Mobilizing its pre-existing network of volunteers and exploiting the emotional appeal of the issue within the broader evangelical community, the OCA successfully collected more than 100,000 signatures and its anti-gay measure was put on the ballot. The measure passed with 53 percent of the vote, and the OCA emerged from the heated and highly publicized campaign as the undisputed champion of Christian conservatism in the state and a force to be reckoned with in Oregon politics.

Following the victory of its anti-gay measure, the OCA turned its attention to the issue of legalized abortion. Within weeks of the Supreme Court's 1989 Webster decision that opened the door for individual states to impose limits on the right to abortion, the OCA filed a petition to put a measure on the November, 1990, ballot to ban abortion in all cases except for rape, incest, or to save the life of the mother. Working in coalition with a number of other anti-abortion groups, the OCA had little difficulty gathering the necessary signatures to put the measure on the ballot. The initiative was eventually defeated by a ratio of two-toone, but the OCA nevertheless gained influence and visibility in the process. In the same election the OCA also sponsored a spoiler thirdparty campaign by its vice-chairman, $\mathrm{Al}$ Mobley, to punish the Republican gubernatorial candidate, Dave Frohnmayer, for not taking anti-gay and anti-abortion positions. The Mobley campaign garnered 13 percent of the vote, throwing the election to the Democratic candidate Barbara Roberts (despite her minority showing) and sending shockwaves through the state Republican establishment.

The central figure in the OCA is Lon Mabon, a born-again Christian who was recruited to the Pentecostal faith by the countercultural Jesus movement in the early 1970s. The OCA operates virtually as a Mabon family business, with Lon, his wife, and both his parents on the OCA payroll, as well as three children who work for the organization. 
The OCA claims a dues-paying membership of between 3,000 and 10,000 according to different newspaper accounts (our data suggest that the first figure is closer to the truth) and a mailing list of 160,000 households (which may also be an inflated figure). The OCA has extensive ties with fundamentalist and Pentecostal/charismatic churches across the state and operates local chapters in all but a few Oregon counties. During the early 1990s the OCA served as the official Oregon affiliate of the Christian Coalition, the largest and most powerful national Christian Right organization. An autonomous statewide Christian Coalition group was formed in 1993, but ties between the two organizations remain strong.

Since its founding, the OCA has worked at the precinct and county levels to establish itself as the dominant force in Oregon Republican Party politics. Mobilization at the precinct level enabled the OCA and its Christian Coalition allies to dominate the state's delegation to the 1996 Republican National Convention. Several times in recent years the OCA and its allies have come close to winning control of the Oregon Republican Party state central committee, losing narrowly in each instance as a result of internal divisions and the opposition of more moderate elements within the party.

The OCA political agenda encompasses a range of traditional rightwing issues, including anticommunism, support for militarism, promotion of business interests, opposition to government regulation, and opposition to welfare spending. However, most of these issues have been little publicized in the face that the OCA presents to the public. Like many Christian Right groups in an era in which anticommunism no longer serves as an effective mobilizing ideology, the OCA has targeted emotionally charged social issues - especially abortion and gay rights - as its chief means of attracting money and members, keeping itself in the media spotlight, and driving a wedge into traditional partisan alignments.

For much of its existence, the OCA has concentrated on the issue of gay rights as its main vehicle of organizational growth. Apart from occasional, politically safe, campaigns (such as organizing rallies to support American troops during the Persian Gulf War), the OCA has directed virtually all of its public outreach since 1990 to the campaign against gay rights. The most highly publicized of these efforts was a 1992 ballot initiative that would have amended the state constitution to: (1) stigmatize homosexuality as "abnormal, wrong, unnatural, and perverse;" (2) ban the use of state or local government monies or facilities from any activity that treated homosexuality in a neutral or positive fashion; and (3) prohibit civil rights protections on the basis of sexual orientation. The initiative was defeated by a margin of 55 to 45 
percent, although majorities in 21 of Oregon's 36 counties supported the measure and several local ordinances patterned after the statewide initiative were approved by voters. A slightly watered down version of the OCA's statewide anti-gay initiative was also defeated in 1994, but by a much smaller margin. The 1994 initiative captured 48.5 percent of the statewide vote and majorities in 25 of the state's 36 counties.

Despite these setbacks at the statewide level, the OCA was able to sustain itself for several years through its successful sponsorship of antigay initiatives at the city and county levels. By the late 1990s, however, the power and influence of the organization began to wane. Negative publicity surrounding the OCA's attacks on gay rights led Republican politicians who had formerly courted OCA endorsement to distance themselves from the controversial organization. ${ }^{4}$ OCA plans for another statewide anti-gay initiative in 1996 were abandoned following the Supreme Court's overturning of a similar Colorado law, and OCA chairman Lon Mabon's quixotic bid for the Republican Senate nomination that year garnered only 8 percent of the vote. A proposed initiative banning same-sex marriages failed to receive sufficient signatures to qualify for the ballot in 1998, as did a second OCA-sponsored measure banning late-term abortions. Currently, the OCA is pinning its revival hopes on sponsorship of an initiative for the 2000 general election that would prohibit Oregon public schools from discussing homosexuality "in a manner which encourages, promotes or sanctions such behaviors."

\section{Data and Hypotheses}

The data for this study were taken from reports filed by the Oregon Citizens' Alliance with the Oregon Election Division between 1987 and 1992. These reports contain the names, addresses, occupations, and employers of all persons who contributed more than $\$ 50$ to the OCA political action committee during any election cycle in this period. The OCA asks a minimum contribution of $\$ 60$ per year to become a member of the organization; hence, most persons who meet this standard should be listed in the reports filed with the state. ${ }^{5}$ I should add that the state of Oregon grants couples a $\$ 100$ per year tax credit for contributions to political action committees (individuals can claim a $\$ 50$ credit). This is not a deduction from taxable income, but a credit from taxes owed; hence, contributions of this magnitude are effectively free to the contributor. This reduces the income bias that ordinarily comes into play when contributions are used to sample the active supporters of an organization. 
After eliminating duplicate entries, these lists provided 3,137 names of OCA contributors. For some entries the data on occupation and employer were incomplete. I therefore consulted city directories from around the state to fill in missing information. The resulting sample consisted of 2,834 OCA supporters for whom addresses were given and for whom data on occupation and employer were reasonably specific. A large share of these contributors consisted of couples, and most of them appear to have listed the husband's occupation and employer. In a few cases occupational information was available on both spouses, and in those cases I used the data on husband's occupation. This was done for reasons of consistency and on the assumption that, in the majority of instances, the husband's occupation provided a better index of family socioeconomic status. Contributors were classified into occupational categories, roughly corresponding to two-digit census occupational codes, and subdivided between self-employed and wage or salary earners. For purposes of comparison, a similar occupational breakdown of the male labor force for the entire state was computed from census data. ${ }^{6}$ OCA supporters were also classified by city and county, and demographic data on these geographic locales were obtained from the census.

In keeping with the findings of previous research on political activism, I expected OCA contributors to resemble activists in other political organizations in the minimal sense that they are likely to be drawn disproportionately from more educated and affluent occupations (e.g., managers and professionals). For obvious reasons, I also expected to find an overrepresentation of clergy among OCA activists. From the status anxiety literature I derived the following, more specific, hypotheses:

1. Small business owners should be one of the most heavily overrepresented groups among OCA activists.

2. Apart from small business owners, other occupations with a marginal claim to middle-class respectability should also be overrepresented among OCA activists. Some proponents of the status anxiety thesis classify routine white-collar employees in this category. I have argued against this specific interpretation of the status anxiety thesis elsewhere (Burris 1986), but will nevertheless examine it in this paper.

3. Within the middle class, occupations that enjoy a high rate of upward mobility from working-class origins should be overrepresented among OCA activists. Research on social mobility shows that this hypothesis largely overlaps with the previous two, since mobility is relatively greater into the ranks of small business owners and routine white-collar occupations than 
it is into the ranks of corporate management and the higher professions. Among the major professions, engineering enjoys the highest mobility from lower occupational ranks (Davis 1965; Perrucci 1969; Collins 1979) and should therefore exhibit disproportionate levels of OCA activism.

And from the belief and value congruity thesis I derived the following hypotheses:

4. Rates of OCA activism should be disproportionately high among persons of advanced age.

5. Rates of OCA activism should be higher in the more rural areas of the state. ${ }^{7}$

\section{Findings}

Not everyone in the sample of OCA supporters reported an occupation and employer, since some were not in the labor force: 427 were retired, 25 were students, and 3 were in the military. The proportion of retirees in the sample (15.1 percent) was only slightly higher than the proportion of males in the state who were 65 years of age or older and not in the labor force (13.1 percent). The hypothesis that OCA activism should be higher among persons of advanced age is therefore not confirmed. Omitting retirees, students, and members of the armed forces left a sample of 2,379 who were currently active in the civilian labor force.

As expected, managerial and professional occupations were overrepresented among OCA supporters. Managers and professionals accounted for 51.5 percent of OCA activists, compared with 23.8 percent of the male labor force in Oregon. The percentage of professionals was elevated slightly by the large number of clergy in the sample. Clergy accounted for 5.2 percent of OCA supporters (compared with 0.6 percent of males in Oregon). Excluding clergy left a sample of 2,255 of whom managers and professionals accounted for 48.9 percent. This sample was used in computing the occupational distributions reported below.

\section{Self-Employed Occupations}

The hypothesis that small business owners should be overrepresented among OCA activists was strongly supported by the data. Overall, the proportion of self-employed among OCA supporters was roughly three times their proportion in the state as a whole (34.4 percent versus 11.6 percent). Figure 1 shows the percentage of self-employed in each major 
occupational group among OCA supporters and in the state as a whole. Self-employed managers and proprietors were the most heavily overrepresented occupations among OCA activists. Their share of OCA supporters was roughly nine times their proportion in the state. ${ }^{8}$ The largest subgroup within this category, independent proprietors in retail trade, was overrepresented by a ratio of approximately 17:1. Self-employed professionals were overrepresented by a ratio of more than 3:1. Small farmers and self-employed craft workers (mainly mechanical repair and construction trades) were overrepresented by a ratio of roughly 2:1.

Small business owners are also heavily overrepresented within the leadership of the OCA. The background of OCA chairman Lon Mabon is illustrative. Mabon was raised in Southern California where his parents ran a small business. Upon his return from Vietnam in 1969, Mabon moved to Eureka, California, where he became active in the

Figure 1. Percentage of OCA Supporters in Self-Employed Occupations

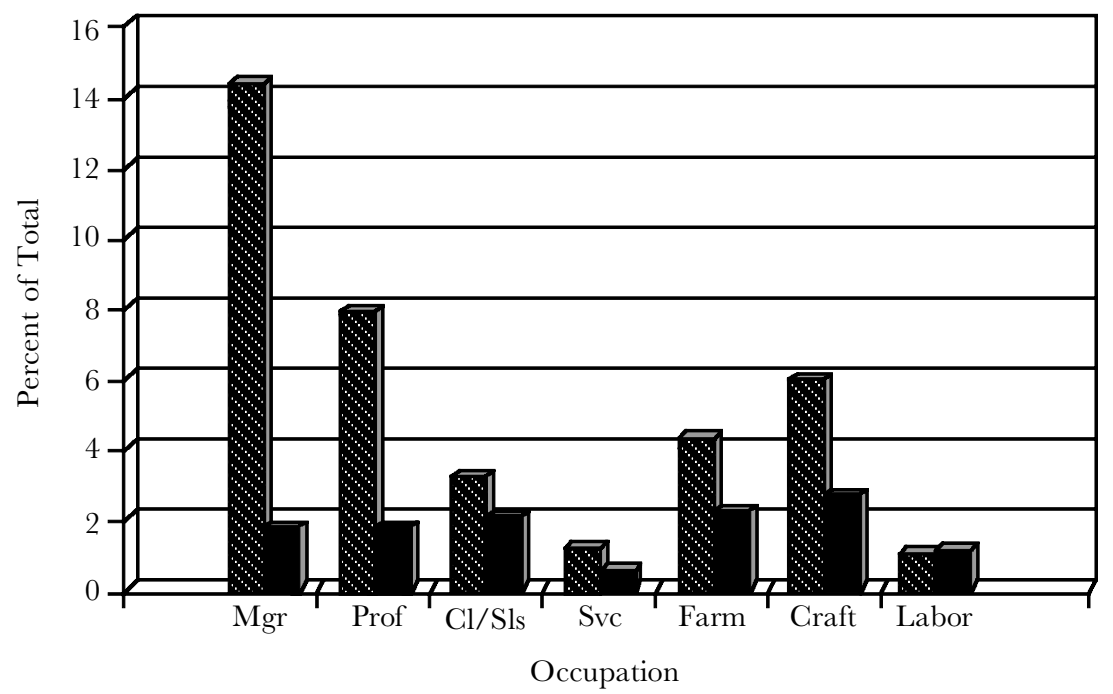

OCA Supporters

Entire State

Key to occupations: Mgr $=$ managers and proprietors; Prof = professionals; $\mathrm{Cl} / \mathrm{Sls}=$ clerical, sales, and technicians; Svc = service; Farm = farming, forestry, and fishing; Craft $=$ precision production, $\mathrm{craft}$ and repair; Labor $=$ operatives, fabricators, and laborers. 
local Pentecostal church. Mabon married and worked for the church for several years. In the late 1970s he and his wife moved to Bishop, California to set up a Christian bookstore and a care home for the elderly. In 1982 the couple moved to Klamath Falls, Oregon to open another elderly care home. Mabon's business ventures were unsuccessful and by 1987, when the OCA was founded, he was more than $\$ 26,000$ in debt to the IRS (Rubenstein 1991). Once the OCA got off the ground, Mabon abandoned his other business ventures to work fulltime for the organization. As noted earlier, the OCA itself functions virtually as a Mabon family business, with Mabon, his wife, and both parents receiving income from the organization.

During the period covered in this study, the OCA had two vicechairmen. The first, Al Mobley, is a retired engineer who worked for the U.S. Army Corps of Engineers (Oregon Alliance 1991a). The second, Kelly Walton, has a background similar to Mabon's. He was raised in Southern California where his father owned a construction company. In the 1970s he settled in Idaho, where he tried his hand (apparently unsuccessfully) at a variety of small business ventures (a fast food restaurant, sports shop, skateboard park, and a grain brokerage business) before moving to Oregon to attend Bible college (Oregon Alliance 1990).

The OCA also has directors (and sometimes deputy directors) in most Oregon counties. I was able to obtain information on the occupation of the head of household of 36 of these county-level leaders for the 1987-92 period. Four were retired. Of the remaining 32, thirteen (41 percent) were self-employed. These included four building contractors, two auto mechanics, an electrician, an accountant, an insurance agent, a chiropractor, a farmer, a lawn and garden store owner, and one whose specific line of business could not be determined.

\section{Salaried Occupations}

The overrepresentation of OCA supporters from the "new" (salaried) middle class (operationalized as salaried managers and professionals) was not as great as among the "old" (self-employed) middle class. In absolute numbers, however, salaried managers and professionals accounted for almost as large a share of OCA activists as small business owners (29.1 percent). Figure 2 shows a breakdown of OCA supporters among salaried occupations. Salaried professionals were overrepresented by a ratio of approximately $2: 1$. Salaried managers were only slightly overrepresented among OCA supporters. Contrary to some interpretations of the status anxiety thesis, lower white-collar employees were not overrepresented 
Figures 2. Percentage of OCA Supporters in Salaried Occupations



S OCA Supporters $\quad$ Entire State

Key to occupations: Mgr $=$ managers and proprietors; Prof = professionals; $\mathrm{Cl} / \mathrm{Sls}=$ clerical, sales, and technicians; Svc = service; Farm = farming, forestry, and fishing; Craft $=$ precision production, craft, and repair; Labor $=$ operatives, fabricators, and laborers.

among OCA supporters. Employees in blue-collar jobs (service occupations, agricultural and forestry workers, skilled crafts, operatives, and laborers) were all significantly underrepresented.

A comparison of the major professions showed engineers to be the most overrepresented category. The percentage of engineers among OCA supporters was approximately 3.5 times their proportion in the state. ${ }^{9}$ Comparable figures for other professions were 2.5 for physicians and dentists, 2.1 for primary and secondary school teachers, 1.0 for college and university teachers, and 0.6 for lawyers. The greater representation of engineers among OCA activists is consistent with the expectations of status anxiety theory; however, one cannot say for sure whether this reflects the higher proportion of new arrivals to the middle class among engineers. It might also be due to the more conservative occupational culture of engineering, the lesser exposure of engineering graduates to a liberal arts education, or the tendency of engineering to attract persons 
with a more conservative upbringing (Davis 1965; Eichhorn 1969; Struening and Lehmann 1969).

\section{Regional Variation}

To examine the hypothesis of disproportionate OCA support from rural areas, I calculated an index of the density of OCA support for each county in the state by dividing the number of OCA activists in the county by the total number of households. I then compared this index with the population density of each county. As expected, the level of OCA activism was below average in the most densely populated region of the state (the Portland metropolitan area). However, the strongest OCA support was not in the most rural areas but in those that were intermediate in population density. Overall, the correlation between the density of OCA activists in each county and county population density was statistically insignificant $(\mathrm{r}=-0.035)$.

A closer look at specific regions of the state will help to clarify this pattern. Approximately two-thirds of the state's population is located in a 100-mile-long corridor (the Willamette Valley) running from Portland in the north to Eugene/Springfield in the south. Multnomah County, which includes most of metropolitan Portland (population 500,000), had an OCA density of 2.1 per thousand households. The two neighboring counties that contain most of suburban Portland (population 500,000) had an OCA density of 2.8 per thousand households. Lane County, which includes the state's second largest urban center, Eugene/Springfield (population 150,000), had an OCA density of 2.4 per thousand households. Between Portland and Eugene/Springfield lies a string of mid-sized towns with populations in the 40,000 to 90,000 range (Salem, Albany, and Corvallis) and surrounding smaller communities. The OCA density in the five counties that comprise this region was 4.9 per thousand households - the highest of any region in the state. The rest of the state is almost exclusively rural, with only a few towns larger than 25,000. The OCA density in these counties was 3.0 per thousand households - a level identical to that of the state as a whole, only slightly higher than the Portland suburbs, and far below the rate for the midWillamette Valley.

The regional variation in OCA support is thus considerably more complex than a simple association between rurality and Christian Right activism would lead us to expect. The two largest cities in the state were relatively low in their density of OCA support; however, the highest rates of OCA activism were not found in the most rural areas. 
Instead, the OCA's strongest base was in mid-sized towns within an hour's drive of larger metropolitan centers. This pattern is compatible with explanations of right-wing activism based on status anxiety, since it is precisely in areas that lie within the shadow of larger cities that the conflicting lifestyles and competing status claims of urban and smalltown society are most acutely experienced. ${ }^{10}$

It should be noted that the geographic distribution of OCA activists is very different from the distribution within the general public of voters who have responded favorably to the OCA's ballot measures. Electoral support for OCA-sponsored ballot measures was more strongly correlated with regional variation in population density. While there was no significant correlation between the density of OCA activists within each county and county population density, the correlation between the percentage of voters approving the OCA's 1992 anti-gay initiative and county population density was highly significant $(\mathrm{r}=-0.520, \mathrm{p}<0.001)$.

Similar differences were found with respect to the association between OCA support and regional socioeconomic characteristics. For example, the density of OCA activists was greatest in counties with a high proportion of college graduates $(r=0.392, p<0.01)$, while the vote for the OCA's 1992 anti-gay initiative was negatively correlated with the percentage of college graduates in each county $(r=-0.718, p<0.001)$. Other county indices of socioeconomic status, such as median family income, median housing value, and percentage of persons in professional and managerial occupations, revealed a similar pattern of positive association with the density of OCA activists and negative association with electoral support for the OCA's 1992 ballot measure. ${ }^{11}$ This merely confirms a point, reiterated in many studies of social movements, that the social composition of movement activists is often very different from that of the broader, but largely passive, constituency to which a movement directs its appeal. It also points to the hazards of making inferences about the social characteristics of Christian Right activists from general surveys of attitudinal support for issues advanced by the Christian Right.

\section{Discussion}

The most outstanding characteristic of OCA activists is the pronounced overrepresentation of small business owners. While small business owners represent slightly more than one-tenth of households in Oregon, they account for more than one-third of OCA members and contributors. This finding is consistent with theories that interpret rightwing activism as a response to status anxiety, insofar as small business 
owners are a group whose economic position and social status are often threatened by market competition and trends toward economic concentration. Of course, until we have more detailed evidence on individual attitudes and motives, we cannot say for certain that status anxiety is indeed the causal mechanism that leads disproportionate numbers of small business owners to become Christian Right activists. There may be other factors associated with small business ownership that contribute to this outcome and these need to be explored before any definitive conclusions can be reached.

Theories that emphasize beliefs and values acquired in childhood would seem to be of little use in explaining the overrepresentation of small business owners among OCA activists. There is no evidence that the childhood socialization of those who become small business owners differs sharply from other groups in terms of moral or religious conservatism. It is possible, of course, that these persons were socialized in a manner that placed an extraordinary emphasis on values of independence and economic success, but this hypothesis merely brings us back to a variant of the theory that emphasizes status concerns as the motivational basis for right-wing activism.

A more plausible alternative is suggested by those who maintain that differential participation in political movements is explained less by discontent or other distinctive social-psychological attributes than it is by the structural features of the recruitment process (McCarthy and Zald 1977; Zurcher et al. 1980; Zurcher and Snow 1981). We know relatively little about the process by which OCA members are recruited. What knowledge we have suggests that the process relies heavily on existing networks of fundamentalist and Pentecostal/charismatic churchgoers, mass mailings to lists of petition signers and donors to other right-wing causes, and publicity in the mass media. On the face of it, none of these recruitment channels would seem to dictate an overrepresentation of small business owners among OCA activists. Until we know more about the details of the recruitment process, however, this alternative explanation cannot be excluded.

Apart from data on the social base of Christian Right activism, the most compelling evidence for the status anxiety thesis comes from analyses of the rhetoric of Christian Right groups. Previous studies have commented on the status concerns that are implicated in the Christian Right's opposition to abortion. According to Petchesky (1984) and Markson (1985), the ideology of the anti-abortion movement reveals a preoccupation with preserving the status of social groups who feel their way of life threatened by changes in women's roles, sexuality, and family relations. Luker (1984) reported that female anti-abortion activists 
are disproportionately full-time homemakers who are limited in the resources needed to compete in what has traditionally been the male sphere (the paid labor force). Anything that reinforces the traditional sexual division of labor is therefore beneficial to their status, since that is where their resources lie. Less has been written about the status implications of the attack on gay rights - the main focus of OCA organizing in Oregon-but it is plausible to argue that increased opportunities for gays and lesbians provides an equally salient target for resentment against the undermining of traditional concepts of gender and family roles (Adam, 1987: 111).

Although there is only limited data on the family situation of OCA activists, it is likely that they resemble Luker's anti-abortion activists in the high proportion who belong to households exhibiting the "traditional" male breadwinner/female homemaker division of labor. One fact we know for certain is that married couples are significantly overrepresented among OCA activists. More than 71 percent of OCA contributors were explicitly listed as married couples, and some of those whose contributions were recorded in the name of an individual are sure to be married as well. This compares with 56 percent of households in the state that are married-couple households. This pattern is consistent with the notion that Christian Right activism is motivated, in part, by concern over the status and viability of "traditional" family arrangements. The high proportion of small business-owning families among OCA activists also fits with this interpretation insofar as the characteristic features of such families (e.g., the common pattern of wives and children working as subordinates within the family business) tend to reinforce traditional family roles and intensify the linkage between family stability economic well-being.

The idea that gay rights threaten the rights and status traditionally accorded to heterosexual marriages is a common theme in the OCA's anti-gay campaign. An article in the OCA newsletter warned:

A major achievement for homosexuals would be the legalization of samesex marriages, giving them the same legal benefits and considerations currently provided to heterosexual marriages. Calling them a "family" would allow custody and/or adoption of children. Homosexual relationships are not only the antithesis to family, but they also threaten its very core (Oregon Alliance, 1991b: 4).

In addition to voicing alarm over threats to the "traditional" family, the rhetoric of the OCA also exhibits more explicitly class-based expressions of status insecurity and resentment. For example, in both its antiabortion and anti-gay campaigns, the OCA has sought to present itself 
as the champion of common, hard-working people whose way of life is threatened by more affluent (but morally corrupt and undeserving) classes. In its anti-abortion campaign, for example, the OCA attributed the easing of legal restrictions against abortion not only to the "anti-family" designs of feminists, but also to the "manipulation of upper class males" who wished to indulge their sexual appetites without incurring the social and financial costs of accidental pregnancies (Oregon Citizens' Alliance 1990a:9, emphasis added). During its anti-gay campaign the OCA made frequent reference to statistics purporting to show that "homosexuals are a rich class" with privileged access to higher education, high-status jobs, and incomes roughly twice the national average (Oregon Citizens' Alliance 1992a: 3). Both campaigns were thus characterized by efforts to mobilize envy and resentment against reputedly more privileged classes. ${ }^{12}$

The rhetoric of the OCA is also revealing in the manner in which it has linked opposition to abortion and gay rights specifically to the economic interests of small business owners. Political appeals that might otherwise appear bizarre or frivolous are more understandable when situated in relation to the economic and status insecurities of the OCA's social base. In its anti-abortion literature, for example, the OCA warned:

HELP WANTED: Entry level employers, such as fast-food restaurants and grocery stores, are experiencing a marked shortage of workers. Why? Abortion is one main cause (Oregon Citizens' Alliance 1990b).

During its 1992 anti-gay campaign the OCA circulated the reputed letter of a hapless apartment owner whose property had repeatedly been damaged by the exotic sexual practices of gay tenants. The letter read:

I really don't care what people do in private, but if it bothers other tenants or damages my buildings I won't stand for it. You can imagine if gay rights laws are passed how apartment owners would be constrained in dealing with conduct like this. You can just hear them saying, "You can't evict me, I'm a homosexual!" When you consider that 60 percent of all rental housing in Oregon is owned by mom and pop operations... it's frightening. Imagine the burden on them (Oregon Citizens' Alliance 1992b: 2).

The most revealing aspect of the OCA's anti-gay campaign, however, is the slogan of "No Special Rights" by which it has sought to redefine the issue of gay and lesbian rights. This slogan, which has proved immensely effective, has allowed the OCA to pose as an opponent of exclusive (usually unspecified) privileges that it claims are provided to or demanded by militant minorities but denied to the general public. By this device the OCA has not only been able to claim the mantle of 
equality for its own cause, but has also framed gay rights as a symbol of more sweeping changes in the rights and status of different groups and a target of more diffuse sentiments of status anxiety. Opposition to "special rights" for gays and lesbians thus provides a conduit for hostility toward other sources of status insecurity whose causes are obscure or which can no longer be openly attacked without risking political marginalization (as with opposition to civil rights for minorities or economic opportunities for women). ${ }^{13}$ More generally, it provides the vehicle for an assault on the expansion of citizenship rights relative to the rights of property, which is the crucial tie that links opposition to gay rights with the broader right-wing political agenda.

\section{Conclusion}

The findings of this study lend support to some of the classical theories of right-wing movements - namely, those that identify status anxiety among marginal segments of the middle class as a motivation for right-wing activism. In particular, I found that the most widely cited example of the "marginal middle class" - the class of small business owners - is heavily overrepresented among OCA activists. Hypotheses derived from the main contending theory-namely, that early socialization predisposes older persons and those residing in rural areas to Christian Right activism - were not supported by this study. Further, I have illustrated how the rhetoric and ideology of the OCA reveal a prevalence of overt and latent themes of status anxiety and resentment.

Theories of status politics have been downplayed or dismissed by many who have studied the New Christian Right (Wallis 1977; Wood and Hughes 1984; Harper and Leicht 1984; Guth and Green 1987; Moen 1988; Tamney and Johnson 1988; Wilcox 1992). Critics have argued that Christian Right activism is better explained in terms of moral beliefs and values acquired through socialization. While there is undoubtedly much to be learned from studying the beliefs and values of Christian Right activists, I see no grounds for abandoning the classical theories of status politics. The uniqueness of the New Christian Right and the differences between religious and secular right-wing movements are easily exaggerated. From this research it appears that the social base of Christian Right activism bears a striking resemblance to that of European fascism and other secular right-wing movements. Theories of status politics have been useful in analyzing these earlier right-wing movements and deserve to be given closer attention in research on the New Christian Right. 
In arguing for this research focus, I am acutely aware of the pitfalls that have characterized the application of status anxiety theories in the past and that have tended to undermine support for this approach. On the one hand, the term "status anxiety" lends itself all too easily to the view that right-wing movements are basically irrational responses to imaginary dangers. This approach is common among liberal scholars who are hostile to right-wing movements and who emphasize their irrational tendencies in order to undermine their legitimacy (e.g., Hofstadter 1967). Without denying the role that irrational motivations and behaviors play in right-wing (or other) social movements, I believe that this is ultimately an unfruitful approach to understanding collective behavior. The politics of the Christian Right are addressed to issues with real consequences for the political entitlements, economic opportunities, and social status of its supporters. The concept of "status anxiety" should focus our attention on the nature of these interests and the social and historical conditions that produced them, rather than treating them as expressions of abnormal psychology.

On the other hand, the association of status anxiety with the "marginal middle class" lends itself all too easily to the idea that affluent and highly educated citizens are immune to the appeal of far right-wing movements. This approach is common among mainstream conservatives who use the theory of status anxiety to exaggerate the difference between the social base and motives of far right-wing movements and the reputedly more "responsible" conservatism of the wealthy classes (e.g., Crawford 1980). It should be emphasized that status anxiety is by no means limited to less affluent strata of the middle class. What matters for the theory of status anxiety is not the absolute level of one's social status but the perception of threats to that status or the disjuncture between one's current status and the status to which one feels entitled. While marginal segments of the middle class, such as small business owners, are heavily overrepresented among right-wing activists, these movements nevertheless recruit from a range of social strata, including many who are better characterized as "upper" or "upper-middle" class (as well as many who are working class). Moreover, the fact that grassroots activists in Christian Right organizations are drawn disproportionately from the middle of the class spectrum should not blind us to the role that patronage by wealthy individuals and alliances with more elite conservative organizations have played in the revival of the Christian Right (Diamond 1989, 1995; Himmelstein 1990).

Finally, it should be emphasized that identifying the social base of the New Christian Right is not the same thing as explaining the emer- 
gence of that movement. These two issues have often been conflated in the status politics literature with the assumption that conditions of strain or discontent lead automatically to political mobilization by affected groups. In opposition to this view, I hold it as axiomatic that an adequate explanation of a social movement can never by constructed purely at the level of social-psychological motives. It is also necessary to analyze the resources that facilitate collective action as well as the institutional aspects of organizational structure, leadership, and recruitment. Developing a clearer picture of who joins the Christian Right and the motives that are implicated in that action is necessary, but not sufficient, for explaining the rise of the New Christian Right.

Notes

1. Similar distinctions can be found in Wallis (1977), Wood and Hughes (1984), and Wilcox (1992).

2. These three variables are explicitly cited as predictors of Christian Right activism by proponents of the belief and value congruity thesis (Wood and Hughes 1984: 89-90; Wilcox 1992: 37). National survey data does support the notion that cultural and moral conservatism - including opposition to gay and lesbian rights - is more widespread among these three demographic groups (Schneider and Lewis 1984).

3. The early history of the OCA is drawn from the excellent pamphlet prepared by the Coalition for Human Dignity (Gardner 1992) and from numerous newspaper reports, of which Moseley (1991) and Rubenstein (1991) were among the most well-researched.

4. An good example is Oregon Republican Senator Gordon Smith. Concluding that endorsement by the OCA had contributed to his defeat when he ran for the Senate in 1994, Smith was quick to repudiate any OCA support when he ran again, successfully, in 1996.

5. There are several ways in which contributors might escape being reported. Persons who contributed $\$ 50$ or less are not reported. These account for roughly 30 percent of all contributions. The OCA sponsors a nonprofit educational trust that is not required to report the names of its contributors. Contributions this trust are roughly 10 percent of contributions to OCA political action committees. The OCA also operates several other political action committees, the largest of which is the "No Special Rights Committee," which is used exclusively to finance the OCA's anti-gay initiatives. There is considerable overlap among contributors to these single-issue PACs and the main OCA committee. Persons who contributed only to these single-issue PACs have not been included in the sample, however, on the assumption that some of them were only expressing support for a specific political issue, rather than allegiance to the OCA as an organization.

6. I used the male labor force as my comparison group since the vast majority of OCA contributors were either males or couples (most of whom listed the husband's occupation and employer). Less than 10 percent of OCA contributions were listed in an individual woman's name.

7. Ideally, I would have preferred data on the kind of region in which OCA activists were raised rather than their current residence. Nevertheless, the proportion of persons from rural or small town backgrounds who currently reside in similar places is much higher than the proportion currently residing in urban areas, so that data on current residence provides a reasonable, if not ideal, test of the socialization thesis.

8. The share of small business owners among OCA supporters was high not only in 
relation to their numbers in the state, but also in relation to the (disproportionately middle-class) fraction of the population that contributes to political campaigns. Using estimates from the 1990 National Election Study (Miller et al. 1991), I found that selfemployed households accounted for roughly 1.5 times the proportion of OCA contributors as they did among political contributors nationally (34.4 versus 22.9 percent); self-employed managers and proprietors accounted for twice the proportion of OCA contributors as they did among contributors nationally (14.2 versus 6.9 percent).

9. The biggest share of these were engineers in computer and electronics firms located in the Portland suburbs and in the urban corridor located south of Portland. An especially high number of OCA supporters (39) were employed by a single firm, Hewlett Packard, located in Corvallis. This casts doubt both on the image of the high-tech computer industry as a locus of cultural modernism and on the stereotype of Christian Right activists as scientific illiterates.

10. An alternative explanation that favors neither theory over the other is that the difficulties and expense of reaching and mobilizing supporters in remote rural areas may have depressed the level of OCA activism there below what it might have been otherwise.

11. The practical significance of this difference was revealed in the OCA's 1992 antigay campaign. In the May primary leading up to the November vote on the OCA's statewide initiative, the OCA sponsored local anti-gay referenda in two cities, Corvallis and Springfield. In Corvallis, a university and research center of 40,000 with the highest percentage of college graduates of any city in the state, the OCA had an exceptionally high density of OCA activists (11.6 per thousand households); nevertheless, the OCA's ballot measure was soundly defeated by the voters. In Springfield, a mill town of 40,000 with virtually the lowest percentage of college graduates of any city in the state, the OCA had only an average density of activists (3.1 per thousand households); nevertheless, their ballot measure passed easily.

12. In this respect, the OCA's rhetoric can be described as a right-wing variant of "populism" - an ideology with historically deep roots in the American middle class, and especially the class of small farmers and small business owners (Lipset 1960). According Kazin (1995), much of the success of the New Christian Right and its allies can be attributed to their adeptness in appropriating this potentially progressive rhetoric and adapting it to cause of social and economic conservatism.

13. For further discussion of the relationship between the Christian Right's opposition to "special rights" for gays and lesbians and its more general ambivalence toward equal rights for women and minorities, see Herman (1997: 128-132).

\section{References}

Adam, Barry D. 1987. The Rise of a Gay and Lesbian Movement. Boston: Twayne Publishers. Bell, Daniel, ed. 1963. The Radical Right. Garden City, NY: Doubleday.

Bracher, Karl Dietrich. 1970. The German Dictatorship. New York: Praeger.

Bruce, Steve. 1988. The Rise and Fall of the New Christian Right. Oxford: Oxford University Press.

Burris, Val. 1986. "The Discovery of the New Middle Class." Theory and Society 15:317-349.

Childers, Thomas. 1976. "The Social Bases of the National Socialist Vote." Fournal of Contemporary History 11:17-42.

Collins, Randall. 1979. The Credential Society. New York: Academic Press.

Crawford, Alan. 1980. Thunder on the Right. New York: Pantheon.

Crespi, Irving. 1971. "Structural Sources of the George Wallace Constituency." Social Science Quarterly 52:115-132.

Davis, James A. 1965. Undergraduate Career Decisions. Chicago: Aldine Publishing. 
Diamond, Sara. 1989. Spiritual Warfare: The Politics of the Christian Right. Boston: South End Press.

1995. Roads to Dominion: Right-Wing Movements and Political Power in the United States. New York: Guilford Press.

Eichhorn, Robert L. 1969. "The Student Engineer." Pp. 141-159 in Robert Perrucci and Joel E. Gerstl, eds., The Engineers and the Social System. New York: Wiley.

Eitzen, D. Stanley. 1970. "Status Inconsistency and Wallace Supporters in a Midwestern City." Social Forces 48:493-498.

Fromm, Erich. 1941. Escape From Freedom. New York: Avon Books.

Gardner, Steve. 1992. Rolling Back Civil Rights: The Oregon Citizens' Alliance at Religious War. Portland, OR: Coalition for Human Dignity.

Geiger, Theodore. 1930. "Panik im Mittelstand." Die Arbeit 7:637-653,

Georgianna, Sharon. 1989. The Moral Majority and Fundamentalism. Lewiston, NY: Edwin Mellon Press.

Gerth, Hans. 1940. "The Nazi Party: Its Leadership and Composition." American fournal of Sociology 45:517-541.

Green, John, and James Gurth. 1988. "The Christian Right in the Republican Party: The Case of Pat Robertson's Supporters." Journal of Politics 50:150-165.

Grupp, Fred. 1969. "The Political Perspectives of the John Birch Society Members." Pp. 83-118 in Robert A. Schoenberger, ed., The American Right Wing. New York: Holt, Rinehart and Winston.

Guerin, Daniel. 1939. Fascism and Big Business. New York: Monad Press.

Guth, James, and John Green. 1987. "God and the GOP." Presented at the annual meeting of the American Political Association, Chicago.

Hamilton, Richard. 1975. Restraining Myths. Beverly Hills, CA: Sage Publications.

1982. Who Voted for Hitler? Princeton: Princeton University Press.

Harper, Charles L. and Kevin Leicht. 1984. "Religious Awakenings and Status Politics: Sources of Support for the New Religious Right." Sociological Analysis 45:339-353.

Herman, Didi. 1997. The Antigay Agenda: Orthodox Vision and the Christian Right. Chicago: University of Chicago Press.

Hofstadter, Richard. 1967. The Paranoid Style in American Politics. New York: Random House. Hunt, Larry L., and Robert G. Cushing. 1970. "Status Discrepancy, Interpersonal Attachment and Right-Wing Extremism." Social Science Quarterly 51:587-601.

Johnson, Stephen, and Joseph Tamney. 1984. "Support for the Moral Majority: A Test of a Model." Journal for the Scientific Study of Religion 23:183-196.

Johnson, Stephen, Joseph Tamney, and Ronald Burton. 1989. "Pat Robertson: Who Supported His Candidacy for President?" Fournal for the Scienfic Study of Religion 28:387-399.

Kazin, Michael. 1995. The Populist Persuasion. Ithaca, NY: Cornell University Press.

Laswell, Harold. 1933. "The Psychology of Hitlerism." Political Quarterly 4:373-384.

Lenski, Gerald. 1954. "Status Crystallization: A Non-Vertical Dimension of Social Status." American Sociological Review 19:405-413.

Lerner, Daniel. 1951. The Nazi Elite. Stanford: Stanford University Press.

Lipset, Seymour M. 1960. Political Man. New York: Anchor Books.

. 1963. "The Sources of the Radical Right." Pp. 307-372 in Daniel Bell, ed., The Radical Right. Garden City, NY: Doubleday.

Lipset, Seymour M., and Earl Raab. 1978. The Politics of Unreason. 2nd ed. Chicago: University of Chicago Press.

Lo, Clarence Y.H. 1982. "Countermovements and Conservative Movements in the Contemporary U.S.” Annual Review of Sociology 8:107-134.

Loomis, Charles P., and J. Allan Beegle. 1946. "The Spread of German Nazism in Rural Areas." American Sociological Review 11:724-734.

Luker, Kristin. 1984. Abortion and the Politics of Motherhood. Berkeley: University of California Press. 
Lunch, William M. 1995. "Oregon: Identity Politics in the Northwest." Pp. 227-251 in Mark J. Rozell and Clyde Wilcox, eds., God at the Grass Roots: The Christian Right in the 1994 Elections. Lanham, MD: Rowman and Littlefield.

Markson, Stephen L. 1985. "The Roots of Contemporary Anti-Abortion Activism." Pp. 33-43 in Paul Sachdev, ed., Perspectives on Abortion. Metuchen, NJ: Scarecrow Press. McCarthy, John D., and Mayer N. Zald. 1977. "Resource Mobilization and Social Movements: A Partial Theory." American Fournal of Sociology 82:1212-1241.

McEvoy, James. 1971. Radicals or Conservatives? The Contemporary American Right. Chicago: Rand McNally.

Mills, C. Wright. 1951. White Collar. New York: Oxford University Press.

Moseley, Joe. 1991. "Mabon Puts Beliefs into Action.” [Eugene] Register-Guard (November 10): $1 \mathrm{~A}, 4 \mathrm{~A}$.

Neumann, Franz. 1951. "Introduction," to Daniel Lerner, The Nazi Elite. Stanford: Stanford University Press.

Oregon Alliance. 1990. "OCA Vice-Chairman Kelly Walton and His Family." Oregon Alliance (November):6. . 1991b. "The Homosexuals' Agenda: Will it Destroy America?" Oregon Alliance (April/May):1, 4.

Oregon Citizens' Alliance. 1990a. Exploding Pro-Abortion Myths [Paid Political Advertisement]. Wilsonville, OR: Oregon Citizens' Alliance.

. 1990b. Oregon's Pro-Life Coalition Initiative Fact Sheet \#1 [Paid Political Advertisement]. Wilsonville, OR: Oregon Citizens' Alliance.

. 1992a. Freedom Fournal [Paid Political Advertisement]. Wilsonville, OR: Oregon Citizens' Alliance.

- 1992b. "Anonymous Letter" [Duplicated and circulated by No Special Rights Committee]. Wilsonville, OR: Oregon Citizens' Alliance.

Petchesky, Rosalind Pollack. 1984. Abortion and Woman's Choice. New York: Longman.

Perrucci, Carolyn Cummings. 1969. "Engineering and the Class Structure.” Pp. 279-310 in Robert Perrucci and Joel E. Gerstl, eds., The Engineers and the Social System. New York: Wiley.

Pratt, Samuel. 1948. "The Social Basis of Nazism and Communism in Urban Germany." M.A. thesis, Michigan State University.

Rohter, Ira. 1969. "Social Psychological Determinants of Radical Rightism.” Pp. 193-237 in Robert A. Schoenberger, ed., The American Right Wing. New York: Holt, Rinehart and Winston.

Rubenstein, Sura. 1991. "Mabon, OCA Wield Political Power." [Portland] Oregonian (July 28):A1, A20.

Rush, Gary. 1967. "Status Consistency and Right-Wing Extremism." American Sociological Review 32:86-92.

Schneider, William and I. A. Lewis. 1984. "The Straight Story on Homosexuality and Gay Rights." Public Opinion 7:16-20, 59-60.

Sigelman, Lee, Clyde Wilcox, and Emmett Buell. 1987. "An Unchanged Minority: Popular Support for the Moral Majority in 1980 and 1984." Social Science Quarterly 68:876-884.

Simpson, John H. 1985. "Status Inconsistency and Moral Issues." Fournal for the Scientific Study of Religion 24:155-162.

Struening, Elmer L., and Stanley Lehmann. 1969. "Authoritarian and Prejudiced Attitudes of University Faculty Members." Pp. 161-199 in Robert Perrucci and Joel E. Gerstl, eds., The Engineers and the Social System. New York: Wiley.

Stryker, Sheldon, and Anne Statham Macke. 1978. "Status Inconsistency and Role Conflict." Annual Review of Sociology 4:57-90.

Tamney, Joseph, and Stephen Johnson. 1983. "The Moral Majority in Middletown." fournal for the Scientific Study of Religion 22:145-157. 
1988. "Exlaining Support for the Moral Majority." Sociological Forum 3:234-255.

Trow, Martin. 1957. "Right-Wing Radicalism and Political Intolerance." Ph.D. thesis, Columbia University.

Wald, Kenneth D., Dennis E. Owen, and Samuel S. Hill, Jr. 1989. "Evangelical Politics and Status Issues." Fournal for the Scientific Study of Religion 28:1-16.

Wallerstein, Immanuel. 1954. "McCarthyism and the Conservative." M.A. thesis, Columbia University.

Wallis, Roy. 1977. "A Critique of the Theory of Moral Crusades as Status Defence." Scottish Journal of Sociology 1:195-203.

Wilcox, Clyde. 1992. God's Warriors: The Christian Right in Twentieth-Century America. Baltimore: Johns Hopkins University Press.

Wilson, Kenneth, and Louis Zurcher. 1976. "Status Inconsistency and Participation in Social Movements." Sociological Quarterly 17:520-533.

Wolfinger, Raymond, Barbara Wolfinger, Kenneth Prewitt, and Sheilah Rosenhack. 1969. "America's Radical Right: Politics and Ideology." Pp. 9-47 in Robert A. Schoenberger, ed., The American Right Wing. New York: Holt, Rinehart and Winston.

Wood, Michael, and Michael Hughes. 1984. "The Moral Basis of Moral Reform." American Sociological Review 49:86-99.

Zurcher, Louis, David Snow, and Sheldon Ekland-Olson. 1980. "Social Networks and Social Movements." American Sociological Review 45:787-801.

Zurcher, Louis, and David Snow. 1981. "Collective Behavior: Social Movements." Pp. 447-482 in Morris Rosenberg and Ralph Turner, eds., Social Psychology: Sociological Perspectives. New York: Basic Books. 